DOI: https://doi.org/10.15407/techned2018.05 $=108$

\title{
NUMERICAL MODELING OF MULTIPHYSICAL PROCESSES FOR ELECTRON-BEAM SCULL MELTING OF TITANIUM
}

Journal

Publisher

ISSN

Issue

Pages
Tekhnichna elektrodynamika

Institute of Electrodynamics National Academy of Science of Ukraine 1607-7970 (print), 2218-1903 (online)

No 5, 2018 (September/October)

$108-111$

\footnotetext{
Author

Y.M. Goryslavets ${ }^{1 *}$, S.V. Ladokhin ${ }^{2}$, O.I. Glykhenkyi ${ }^{1 * *}$, T.V. Lapshuk ${ }^{2}$, O.I. Bondar ${ }^{1}$, E.O., Drozd

2

1 - Institute of Elektrodynamics of the National Academy of Sciences of Ukraine,

pr. Peremohy, 56, Kyiv, 03057, Ukraine,

e-mail: gai56@ied.org.ua

2 - Physico-Technological Institute of Metals and Alloys of the National Academy of Sciences of Ukraine,

Vernadsky blvd., 34/1, Kyiv, 03142, Ukraine,

e-mail: e_luch@ptima.kiev.ua

* ORCID ID : http://orcid.org/0000-0003-1668-4972

** ORCID ID : http://orcid.org/0000-0001-5053-5677
}

With the aim of improving of scull crucible design with system of electromagnetic stirring of liquid metal, increasing of energy efficiency and determining of rational technological regimes of electron-beam scull melting three dimensional mathematical model for numerical investigation of electromagnetic, hydrodynamic and heat processes during melting has been developed. For simplicity, mentioned processes was considered as stationary. The influence of basic crucible 
sizes ratio and direction of metal flow during electromagnetic stirring on efficiency of melting process was investigated. References 3 , figures 3.

Key words: electron beam scull melting, scull crucible, system of electromagnetic stirring, mathematical modelling, electromagnetic, hydrodynamic and heat processes.

Received: 02.03 .2018

Accepted: 19.03 .2018

Published: 16.08 .2018

\section{References}

1. Glukhenkyi A.I., Goryslavets Y.M., Bondar A.I., Ladokhin S.V., Lapshuk T.V., Drozd E.A. The modeling of electron-beam melting of titanium in skull crucible. Protsessy litia. 2017. No 2. Pp. 30-38. (Rus)

2. Kays W.M. Turbulent Prandtl number-where are we? ASME Journal of Heat Transfer. 1994. Vol. 116(2). Pp. 284-295.

DOI:

https://doi.org/10.1115/1.2911398

3. Bojarevics V., Harding R.A., Pericleous K. and Wickins M. The Development and Experimental Validation of a Numerical Model of an Induction Skull Melting Furnace. Metallurgic al and Materials Transactions . 2004. Vol. 35 B. Pp. 785-803. 
